\title{
Erratum to: Wnt and Notch signaling pathway involved in wound healing by targeting c-Myc and Hes 1 separately
}

Yan Shi ${ }^{1+}$, Bin Shu ${ }^{1 \dagger}$, Ronghua Yang ${ }^{2}$, Yingbin Xu' ${ }^{1}$ Bangrong Xing ${ }^{3}$, Jian Liu ${ }^{1}$, Lei Chen ${ }^{1}$, Shaohai Qi ${ }^{1}$, Xusheng Liu', Peng Wang ${ }^{1}$, Jinming Tang ${ }^{1}$ and Julin Xie

\section{Erratum}

After publication of this article [1] we were informed that the affiliation for Dr Yan Shi was incorrectly listed as Department of Medical Cosmetology, Jiangxi Maternal and Child Health Hospital. Dr Shi's correct affiliation should have been given as Department of Burns Surgery, First Affiliated Hospital of Sun Yat-Sen University. Dr Shi's affiliation has been corrected here.

Please note that the email address for Dr Bin Shu has changed since the publication of our original article. The correct e-mail address is shubin29@sina.com.

\section{Author details \\ ${ }^{1}$ Department of Burns Surgery, First Affiliated Hospital of Sun Yat-Sen University, Zhongshan Road, Guangzhou 510080, China. ${ }^{2}$ Department of Burns, Fo Shan Hospital of Sun Yat-Sen University, Lingnan Avenue, Foshan 528000, China. ${ }^{3}$ Department of Burns, Third Affiliated Hospital of Sun Yat-sen University, Tianhe Road, Guangzhou 510620, China.}

Received: 8 September 2015 Revised: 10 December 2015 Accepted: 13 December 2015 Published online: 18 December 2015

\section{Reference}

1. Shi Y, Shu B, Yang R, Xu Y, Xing B, Liu J, et al. Wnt and Notch signaling pathway involved in wound healing by targeting c-Myc and Hes1 separately. Stem Cell Res Ther. 2015;6:120. doi:10.1186/s13287-015-0103-4.

\footnotetext{
* Correspondence: xiej190@sina.com

${ }^{\dagger}$ Equal contributors

'Department of Burns Surgery, First Affiliated Hospital of Sun Yat-Sen

University, Zhongshan Road, Guangzhou 510080, China

Full list of author information is available at the end of the article

Submit your next manuscript to BioMed Central and we will help you at every step:

- We accept pre-submission inquiries

- Our selector tool helps you to find the most relevant journal

- We provide round the clock customer support

- Convenient online submission

- Thorough peer review

- Inclusion in PubMed and all major indexing services

- Maximum visibility for your research

Submit your manuscript at www.biomedcentral.com/submit 